\author{
K. S. Marakasova, B. O. Ostash, V. O. Fedorenko \\ Ivan Franko National University of Lviv, Grushevsky str., 4, \\ Lviv, 79005, Ukraine; e-mail:v_fedorenko@franko.lviv.ua
}

\title{
NEGATIVE REGULATION OF MOENOMYCIN A BIOSYNTHESIS IN STREPTOMYCES GHANAENSIS ATCC 14672
}

\begin{abstract}
Members of the soil-dwelling prokaryotic genus Streptomyces produce around twothirds of all known antibiotics. Moenomycin $A$ is a potent antibacterial drug against many Gram-positive pathogens, including vancomycin-resistant pathogens. Studying of moenomycin A biosynthesis regulation is of great importance because of need of new tools for combinatorial biosynthesis. In this work we examined the effects of known pleiotropic regulator DasR on moenomycin biosynthesis under heterologous conditions. DasR controls several pivotal cellular processes, including the transport of $N$-acetylglucosamine (GlcNAc), ubiquitous metabolite and an important source of carbon and nitrogen in soil ecosystems. Gene dasR was inactivated in $S$. coelicolor and moenomycin biosynthetic gene cluster was expressed in the mutant and parent strains. Moenomycin production increased twofold in dasR-deficient strain, confirming the involvement of DasR in regulation of phosphoglycolipid production.
\end{abstract}

$K e y$ wo $r d$ s: streptomycetes, moenomycin $A$, regulator DasR, $\mathrm{N}$-acetylglucosamine.

Streptomycetes are complex multicellular Gram-positive soil bacteria, perhaps best known for their ability to produce over two-thirds naturally derived antibiotics. Moenomycin A (MmA) is produced by Streptomyces ghanaensis ATCC14672. Moenomycin A (MmA) is a member of the phosphoglycolipid family of antibiotics, which are the only natural products known to directly target the extracellular peptidoglycan glycosyltransferases involved in bacterial cell wall biosynthesis. The emergence of resistance to existing antibiotics represents a significant threat to public health. New antibiotics with activity against resistant bacterial strains are desperately needed. The structural and biological uniqueness of $\mathrm{MmA}$ make it an attractive starting point for the development of new antibacterial drugs.

The entire MmA biosynthetic (moe) gene cluster from the producer Streptomyces ghanaensis ATCC14672 was cloned and sequenced [1]. The regulation of moe cluster gene expression is unclear because it appears to lack dedicated regulatory genes. The aim of this work is to find genes that can regulate $M m A$ biosynthesis. Particularly we focused our attention on gene das $R$, encoding a protein involved in regulation of transport and metabolism of N-acetylglucosamine (GlcNAc). The latter is a breakdown product of chitin, widely represented polymer in soils. Two molecules of GlcNAc are also present in the $\mathrm{MmA}$, and, therefore, it is logically to suppose that DasR might somehow be implicated in regulation of $\mathrm{MmA}$ production. We addressed this question through expression of $M m A$ gene cluster and subsequent analysis of MmA production levels in dasR-deficient and parent strains of S. coelicolor M145.

(C) K. S. Marakasova, B. O. Ostash, V. O. Fedorenko, 2009 


\section{Materials and methods}

Plasmids and Streptomyces strains used in this work are listed in Table. E. coli ET12567 (pUB307) was used to perform intergeneric conjugation from E. coli to Streptomyces strains. Sarcina lutea was used as a test-culture for antibiotic activity test.

Table

Plasmids and Streptomyces strains

\begin{tabular}{|c|c|c|}
\hline Plasmid/Strain & Genotype/description & Source/reference \\
\hline moeno38-5 & $\begin{array}{l}\text { Contains major portion of moe cluster 1, } \\
\text { Ap }^{r} \operatorname{Hyg}^{r} \mathrm{Km}^{\mathrm{r}}\end{array}$ & $\begin{array}{l}\text { Ostash B., } \\
\text { Lviv University }\end{array}$ \\
\hline cosmid SC7E4 & $\begin{array}{l}\text { Contains a fragment of } S \text {. coelicolor genome with } \\
\text { insertion of modified Tn5 transposon into dasR } \\
\text { coding sequence; } A p^{r} A m^{r} \mathrm{Km}^{r}\end{array}$ & $\begin{array}{l}\text { Dyson P.J., } \\
\text { University of Wales } \\
\text { Swansea }\end{array}$ \\
\hline $\begin{array}{l}\text { S. ghanaensis } \\
\text { ATCC14672 }\end{array}$ & Wild-type producer of $\mathrm{MmA}$ & ATCC \\
\hline $\begin{array}{l}\text { S. coelicolor } \\
\text { M145 }\end{array}$ & $\begin{array}{l}\text { SCP1; SCP2; model strain, produces actinorho- } \\
\text { din and undecylprodigisin }\end{array}$ & $\begin{array}{l}\text { M. Bibb, } \\
\text { John Innes Centre }\end{array}$ \\
\hline $\begin{array}{l}\text { S. coelicolor } \\
\text { M145 dasR }\end{array}$ & dasR mutant, $\mathrm{Am}^{\mathrm{r}}$ & This study \\
\hline $\begin{array}{c}\text { M145 } \Delta \text { dasR } \\
\text { moeno38-5+ }\end{array}$ & S. coelicolor M145 $\Delta$ dasR carrying moeno38-5 & This study \\
\hline M145 moeno38-5+ & S. coelicolor M145 carrying moeno38-5 & This study \\
\hline
\end{tabular}

Standard genetic techniques for E. coli and Streptomyces and for DNA manipulations were used as described by Sambrook et al. [2] and Kieser et al. [3]. Streptomyces strains were grown in liquid TSB media for MmA production. Streptomyces strains were grown on rich (R2YE) and minimal medium (MM) for estimate the effect of N-acetylglucosamine on the production of the pigmented antibiotics. E. coli and Sarcina strains were grown in LB supplemented with appropriate antibiotics. Oatmeal medium was used to obtain spores of streptomycetes and to plate intergeneric matings. Where needed, streptomycete strains were incubated in the presence of

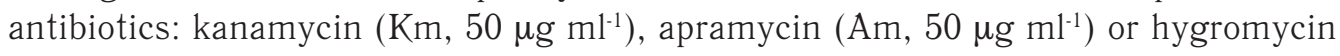
(Hyg, $100 \mu \mathrm{g} \mathrm{m} \mathrm{m}^{-1}$ ). MmA was extracted by stirring the biomass ( $1 \mathrm{~g}$, wet weight) with $3 \mathrm{ml}$ of methanol for $12 \mathrm{~h}$. The extract was concentrated in vacuo and diluted to the final volume of $300 \mu \mathrm{l}$. For the antibiotic diffusion assay, paper discs $(\varnothing 5 \mathrm{~mm}$, Whatman) were impregnated with a portion of the extract and dried at $37^{\circ} \mathrm{C}$ for $1 \mathrm{~h}$. Discs were placed on the plates with $0.7 \%$ soft agar containing S. lutea. The plates were incubated at $4{ }^{\circ} \mathrm{C}$ for $1 \mathrm{~h}$ and then at $37^{\circ} \mathrm{C}$ for $17 \mathrm{~h}$. The productivity of the strains was referred back to the equal weight of the dry biomass.

\section{Results and discussion}

Bioinformatics research has revealed the presence of two genes homologous to GntR-type regulator dasR within the genome of S. ghanaensis ATCC14672. Probably, DasR is involved in control of the Streptomyces sugar phosphotransferase system, responsible for import of several carbon sources, most notably $\mathrm{N}$-acetylglucosamine, the monomer of chitin. In literature, binding of $S$. coelicolor DasR protein to the consensus 
sequence (DasR-responsive element (dre)) is well documented [4]. We have detected two putative dre elements within $S$. ghanaensis ATCC14672 genome. These elements are located within promoters upstream of two genes involved in MmA's carbohydrate portion assembly (moeE5: TTGGTCCGGACA, moeGT5: TCGGTCGGGCCC).

For knock-out of dasR gene in S. coelicolor M145 a cosmid SC7E4.1 (tab.) has been used. Phenotype of the generated mutant was confirmed via PCR analysis. We have confirmed the effect of $\mathrm{N}$-acetylglucosamine on the production of the pigmented antibiotics of mutant grown on rich (R2YE) and minimal medium (MM) agar plates with/without $\mathrm{N}$-acetylglucoseamine. For heterologous expression of $\mathrm{MmA}$ biosynthesis gene cluster, S. coelicolor M145 $\Delta$ dasR (moeno38-5) and S. coelicolor M145 (moeno38-5) strains were constructed. Antibiotic activities of generated mutants were tested with the help of test-culture Sarcina lutea. Our data show that in liquid medium $S$. coelicolor $\Delta d a s R$ strain produces two times more moenomycin as compared to initial strain (M145). Thus DasR regulator seems to be involved in regulation of $\mathrm{MmA}$ biosynthesis.

Our study showed that $S$. coelicolor DasR could be involved in regulation of $M m A$ biosynthesis. This is also supported by bioinformatic evidence for presence of two dasR-like ORFs and two putative dre sequences within moe cluster of $S$. ghanaensis. Probably DasR binds dre sequences in this way repressing MmA biosynthesis. It will be interesting to investigate the role of DasR in MmA producer, S. ghanaensis ATCC14672, which contains two genes highly homologous to S. coelicolor dasR. We suppose that DasR is not a single global negative regulator involved in $M \mathrm{~mA}$ biosynthesis and more extensive search will turn up other repressors and activators of $\mathrm{MmA}$ production. Their rational manipulation will form a basis for improvement of $\mathrm{MmA}$ titers in native and heterologous producers.

\section{REFERENCES}

1. Ostash B., Saghatelian A., and Walker S. A Streamlined Metabolic Pathway for the Biosynthesis of Moenomycin A // Chemistry \& Biology. - 2007. - 14, № 3. - P. 257-267.

2. Sambrook J. and Russel D.W. Molecular Cloning. A Laboratory Manual. $-3^{\text {rd }}$ ed. - Cold Spring Harbor Laboratory, NY, 2001. - 2713 p.

3. Kieser T., Bibb M., Buttner M.J., Chater K.F. and Hopwood D.A. Practical Streptomyces genetics. - Norwich: The John Innes Foundation, 2000. - 613 p.

4. Rigali S., Nothaft H., Noens E.E., Schlicht M., Colson S., Moller M., Joris B., Koerten H.K., Hopwood D.A., Titgemeyer F., van Wezel G.P. The sugar phosphotransferase system of Streptomyces coelicolor is regulated by the GntR-family regulator DasR and links N-acetylglucosamine metabolism to the control of development // Mol. Microbiol. - 2006. - 61, № 5. P. 1237-1251.

\section{Е. С. Маракасова, Б. О. Осташ, В. А. Федоренко}

Львовский национальный университет имени Ивана Франко, ул. Грушевского, 4 , Львов, 79005, Украина; e-mail: v_fedorenko@franko.lviv.ua

\section{НЕГАТИВНАЯ РЕГУЛЯЦИЯ БИОСИНТЕЗА МОЕНОМИЦИНА А В UTAMME STREPTOMYCES GHANAENSIS ATCC 14672}

\section{Реферат}

Проведен биоинформатический анализ генома S. ghanaensis ATCC14672. В геноме S. ghanaensis обнаружены два гена, гомологичных гену dasR в S. coelicolor, 
продукт которого является членом семейства регуляторов GntR. DasR-плейотропный регулятор, который негативно регулирует биосинтез антибиотиков, метаболизм $\mathrm{N}$-ацетилглюкозамина и спрообразование. В кластере генов биосинтеза моеномицина А идентифицированы вероятные последовательности $d r e$, с которыми может связываться белок DasR. Получено нокаут гена dasR в штамме S. coelicolor M145. Для штамма дикого типа M145 характерно увеличение синтеза пигментированных антибиотиков актинородина и ундецилпродигиозина на минимальной среде с добавлением $\mathrm{N}$-ацетилглюкозамина. Такого эффекта не наблюдалось в штамме с нокаутом гена dasR (S. coelicolor M145 $\Delta$ dasR). Осуществлена гетерологическая экспрессия кластера генов биосинтеза моеномицина А в штаммах S. coelicolor M145 $\Delta$ das $R$ и S. coelicolor M145. Анализ антибиотической активности этих штаммов показал, что ген dasR S. coelicolor M145 негативно регулирует экспрессию генов биосинтеза моеномицина А. Синтез моеномицинов в штамме с нарушенным геном das $R$ был вдвое выше, чем в штамме S. coelicolor, который содержит функциональный ген dasR.

K л ю ч е в ы е с л о в а: стрептомицеты, моеномицин A, регулятор DasR, $\mathrm{N}$-ацетилглюкозамин.

\section{К. С. Маракасова, Б. О. Осташ, В. О. Федоренко}

Львівський національний університет імені Івана Франка, вул. Грушевського, 4 , Львів, 79005, Україна; e-mail: v_fedorenko@franko.lviv.ua

\section{НЕГАТИВНА РЕГУЛЯЦІЯ БІОСИНТЕЗУ МОЕНОМІЦИНУ А У ШTAMI STREPTOMYCES GHANAENSIS ATCC 14672}

\section{Реферат}

Проведено біоінформативний аналіз геному S. ghanaensis ATCC14672. У геномі S. ghanaensis виявлено два гени, гомологічні до гена dasR S. coelicolor, продукт якого належить до родини регуляторів GntR. DasR-плейотропний регулятор, задіяний у негативній регуляції біосинтезу антибіотиків, метаболізму $\mathrm{N}$-ацетилглюкозаміну та спороутворення. У межах кластера генів біосинтезу моеноміцину А ідентифіковано імовірні послідовності $d r e$, з якими може зв'язуватись білок DasR. Отримано нокаут гена dasR в штамі S. coelicolor M145. Для штаму дикого типу M145 характерне зростання синтезу пігментованих антибіотиків актинородину та ундецилпродигіозину на мінімальному середовищі при додаванні N-ацетилглюкозаміну. Натомість такого зростання не спостерігали у штамі з нокаутом гена dasR (S. coelicolor M145 $d a s R)$. Здійснено гетерологічну експресію кластера генів біосинтезу моеноміцину А у штамах S. coelicolor M145 та S. coelicolor M145 d dasR. Аналіз антибіотичної активності цих штамів виявив, що ген dasR S. coelicolor M145 негативно регулює експресію генів біосинтезу моеноміцину А. Синтез моеноміцинів у штамі зі зруйнованим геном dasR удвічі вищий порівняно зі штамом S. coelicolor M145, що містить функціональний ген $d a s R$.

K л ю ч о в і с л о в а: стрептоміцети, моеноміцин A, регулятор DasR, $\mathrm{N}$-ацетилглюкозамін. 